\title{
Distres sebagai Mediator antara Resiliensi dan Well-being pada Dewasa di Indonesia
}

\section{Fariza Nur Shabrina, Ni Putu Putri Puspitaningrum}

Program Studi Magister Profesi, Fakultas Psikologi, Universitas Indonesia, Jakarta

Grace Elizabeth Romorani Sigumonrong

Program Studi Sarjana Kedokteran, Fakultas Kedokteran, Universitas Sumatera Utara, Medan

\section{Nabila Isnandini}

Program Studi Sarjana Psikologi, Fakultas Psikologi, Universitas Indonesia, Jakarta

\section{Syora Alya Eka Putri}

Program Studi Magister Sosiologi, Fakultas Ilmu Sosial dan Ilmu Politik, Universitas Indonesia, Jakarta

Abstrak: Pada situasi stres, resiliensi dinilai sebagai faktor protektif dari well-being yang ditandai dengan optimisme dan fleksibilitas kognitif. Individu yang resilien dengan kata lain berpotensi memiliki persepsi distres psikologis rendah sehingga memiliki well-being yang baik bahkan selama perubahan ini terjadi. Penelitian ini bertujuan untuk melihat peran distres psikologis sebagai mediator dalam hubungan antara resiliensi dan well-being pada dewasa Indonesia. Partisipan dewasa berusia 18 tahun ke atas diminta untuk mengisi survei online berbentuk selfreported inventory yaitu HSCL-10, RS-14, dan MHC-SF. Hasil analisis mediasi dari 260 partisipan menunjukan bahwa distres psikologis berperan sebagai mediator parsial dalam hubungan antara resiliensi dan well-being ( $\hat{a}=.14 ; S E=.03 ; 95 \%$ CI $[.09, .19])$. Semakin tinggi resiliensi, maka semakin positif individu melihat situasi mereka yang ditandai dengan rendahnya distres psikologis. Distres psikologis yang rendah kemudian berpengaruh terhadap peningkatan wellbeing, ini juga berarti bahwa hipotesis diterima. Hasil penelitian ini menguatkan pentingnya peran persepsi kognitif terhadap well-being dalam menghadapi situasi stres.

Kata Kunci: distres psikologis, resiliensi, well-being

\section{Distress Mediates the Relationship between Resilience and Well-Being among Indonesian Adults}

Abstract: When faced with stressful times, resilience is said to be a protective factor of wellbeing characterized by optimism and cognitive flexibility. Thus, resilient individuals may be less likely to perceive their situation as distressful, and in turn they display better well-being even during stressful events. This study examined the role of psychological distress as a mediator in the relationship between resilience and well-being among adults in Indonesia. Adult participants aged 18 years and above were asked to complete self-reported online surveys of HSCL-10, RS14 , and MHC-SF. The mediation analysis result of 260 participants showed that psychological distress was a significant partial mediator in the relationship between resilience and wellbeing. The higher the resilience, the more positive the individual perceives their situation, which is characterized by lower psychological distress. Low psychological distress then affects the increase in well-being ( $\hat{a}=.14 ; S E=.03 ; 95 \% \mathrm{CI}[.09, .19])$. This study result highlights the importance of cognitive perception on well-being during stressful events.

Keywords: psychological distress, resilience, well-being

Korespondensi: Fariza Nur Shabrina. Email: fariza.nur91@ui.ac.id 
Keadaan pandemi COVID-19 merupakan situasi tidak terduga yang membawa banyak perubahan pada kehidupan masyarakat. Perubahan-perubahan yang ada dapat mempengaruhi kondisi psikologis masyarakat, diantaranya penurunan well-being (Gallè et al, 2020; Organization, 2020; Wang et al, 2020). Well-being sendiri sering diteliti pada berbagai situasi krisis atau menunjukkan perubahan besar, seperti bencana alam, perubahan kondisi hidup, maupun tragedi (Luhmann, 2014; Makwana, 2019). Karena cakupannya yang luas, well-being banyak diteliti untuk melihat bagaimana perubahan yang terjadi mempengaruhi kehidupan dan kualitas hidup yang dimiliki oleh individu (Weeranakin \& Promphakping, 2018).

Penelitian Keyes (2002) sendiri mendefinisikan well-being ini sebagai persepsi dan evaluasi individu terhadap hidup mereka dalam lingkup emosional, psikologis, dan fungsi sosial. Pada penelitian Keyes (2002) juga mengklasifikasikan well-being menjadi 3 dimensi yaitu, emotional well-being, psychological well-being, dan social well-being. Mengalami perasaan positif, tidak hadir perasaan negatif, dan persepsi puas terhadap hidup merupakan bagian dari dimensi emotional well-being. Sementara itu, selfacceptance, hubungan positif yang baik dengan pihak lain, pengembangan diri, makna hidup, environmental mastery, dan autonomy dapat diklasifikasikan ke dalam dimensi psychological well-being serta cenderung dipersepsikan lebih personal dan subjektif. Terakhir, dimensi social well-being mengukur kriteria keberfungsian di mata masyarakat serta mencakup social coherence, social actualization, social integration, social acceptance, dan social contribution (Keyes, 2002). Cara untuk meningkatkan well-being setelah terjadi perubahan itu sering juga menjadi objek penelitian, akan tetapi salah satu faktor yang paling sering diteliti dan terbukti dapat berkontribusi untuk meningkatkan wellbeing individu (Harms et al., 2018) maupun komunitas (McCrea et al., 2014) adalah resiliensi.

Resiliensi dapat diartikan sebagai kapasitas individu untuk beradaptasi terhadap dinamika sistem yang kompleks dan ketidakpastian yang berpotensi mengancam keberfungsian, kelangsungan hidup, maupun perkembangan diri (Masten, 2018; Wald, 2020). Resiliensi berkaitan dengan koping aktif, dimana individu menyadari pemikiran tentang situasi yang dihadapi dan secara aktif meminimalkan penilaian ancaman (tetapi tidak menyangkal ancaman) sehingga tidak dikonsumsi oleh rasa takut (Iacoviello \& Charney, 2014). Resiliensi terdiri dari berbagai aspek psikososial yang mempengaruhi tingkat resiliensi setiap individu (Pietrzak et al., 2010). Aspek psikososial tersebut diantaranya adalah optimisme, fleksibilitas kognitif, koping aktif, jaringan sosial, dan prinsip moral (Iacoviello \& Charney, 2014; Southwick et al., 2005). 
Optimisme merupakan aspek kognitif di mana seseorang memiliki pandangan yang secara umum positif terkait masa depan (Carver et al., 2010). Adanya optimisme ini berperan dalam meningkatkan suasana hati dan kemampuan untuk bertahan. Fleksibilitas kognitif merupakan keluwesan persepsi seseorang terhadap tantangan yang dihadapi; mencari makna dan hasil positif, serta mengakui dan menyadari konsekuensi negatif dari suatu tantangan (Iacoviello \& Charney, 2014). Mekanisme koping aktif dan dukungan jejaring sosial berperan dalam membuat individu tidak merasa sendirian, mendapat kekuatan untuk menghadapi trauma, serta meminimalkan rasa putus asa (Rossouw \& Rossouw, 2016). Adapun prinsip moral dalam bentuk kesadaran akan tujuan dan makna hidup membantu individu lebih adaptif dalam berpikir dan mencegah keputusasaan melihat masa depan (Ledesma, 2014; Russo-Netzer, 2019).

Melalui aspek-aspek psikososial yang telah dijelaskan, resiliensi kemudian dapat mempengaruhi well-being yang dimiliki oleh individu. Individu dengan resiliensi tinggi menunjukkan respon positifyang memperluas lingkup pemikiran dan fleksibilitas yang bermanfaat pada well-being terkait dengan mengatasi tantangan dan mencapai sasaran pribadi (Mayordomo et al, 2016). Resiliensi juga ditandai oleh adanya self-esteem yang tinggi dan berperan dalam meningkatkan persepsi terkait well-being dan kepuasan hidup (Liu et al, 2014). Individu yang resilien juga lebih aktif dalam melakukan koping dalam menghadapi stres serta memanfaatkan dukungan sosial yang ia miliki, di mana dukungan sosial yang memadai juga bisa meningkatkan well-being (Zhang et al, 2017).

Pengaruh resiliensi terhadap well-being salah satunya dapat dijelaskan oleh peran distres psikologis. Hubungan distres psikologis dengan resiliensi telah dilihat dalam berbagai penelitian, dan terlihat bahwa resiliensi dapat menurunkan tingkat distres psikologis (Bacchi \& Licinio, 2017; Harker et al, 2016; Stomff, 2019). Hal ini berkaitan juga dengan karakteristik kognitif dari resiliensi yaitu optimisme dan fleksibilitas kognitif. Resiliensi membuat individu melihat situasi dan masa depan secara lebih positif, di mana individu tersebut melihat stressor sebagai tantangan dan bukan ancaman (Bacchi \& Licinio, 2017). Melalui pola pikir yang lebih positif ini, individu merasakan lebih banyak emosi positif memiliki harapan akan masa depan, serta menunjukkan keyakinan diri dalam menghadapi distres psikologis (Cher \& Aileen, 2015; Fedina et al., 2021; Tian et al, 2016).

Distres psikologis dikaitkan dengan persepsi negatif terhadap stressor yang dapat menyebabkan gejala depresi, dorongan mengakhiri hidup, dan kecemasan (Lebares et al., 2018). Adanya distres psikologis ini meningkatkan perasaan negatif sehingga dapat menurunkan tingkat well-being yang ditandai dengan ketidakpuasan seseorang dalam hidupnya (Datta Gupta et al., 2016; 
Marino et al., 2018; Wersebe et al., 2018; Zacher \& Rudolph, 2021). Sebaliknya, distres psikologis yang rendah dihubungkan dengan peningkatan terhadap well-being individu ( $\mathrm{Li}$ \& Hasson, 2020). Oleh karenanya, ketika resiliensi yang tinggi membuat persepsi akan situasi lebih positif dan menurunkan distres psikologis, individu menilai situasinya secara lebih baik dan lebih puas akan hidupnya sehingga meningkatkan wellbeing. Dengan kata lain, distres psikologis dapat menjadi mediator parsial dalam hubungan antara resiliensi dengan wellbeing.

Penelitian terkait resiliensi dan wellbeing telah diteliti sebelumnya di Indonesia, namun belum ada yang berusaha melihat dinamika di balik bagaimana resiliensi dapat mempengaruhi well-being. Penelitian ini bertujuan untuk melihat peran distres psikologis sebagai mediator dalam hubungan antara resiliensi dan well-being, yang dilakukan pada dewasa di Indonesia. Resiliensi diteliti mampu memberikan dampak positif terhadap well-being, di mana dampak ini bisa dilihat melalui perubahan tingkat distres psikologis pada individu. Salah satu bentuk reaksi terhadap sumber stres adalah distres psikologis, dan penelitian terkait variabel ini dapat menjadi pertimbangan dalam merumuskan intervensi psikologis yang efektif dalam menjaga wellbeing dalam situasi penuh tekanan.

\section{Metode}

\section{Partisipan dan prosedur}

Penelitian ini menggunakan pendekatan kuantitatif dengan pengumpulan data melalui survei daring. Pengambilan survei daring menggunakan platform Google Form, yang disebar melalui media sosial mulai tanggal 1 Juli hingga 31 Agustus 2020. Teknik pengambilan sampel menggunakan teknik non random sampling yaitu insidental. Kriteria responden dalam penelitian ini adalah penduduk Indonesia berusia dewasa (diatas 18 tahun). Setiap partisipan telah memberikan lembar persetujuan partisipasi. Prosedur penelitian ini mengikuti kaidah etik penelitian psikologi dan telah mendapatkan persetujuan dari Tim Kaji Etik Fakultas Psikologi Universitas Indonesia.

\section{Pengukuran}

Penelitian ini menggunakan tiga alat ukur psikologis dalam bentuk self-reported inventory untuk mengukur variabel-variabel yang ada. Ketiga alat ukur tersebut adalah:

\section{Hopkins Symptom Checklist (HSCL-10)}

Sejak pertama kali disusun pada tahun 1954 oleh Parloff, Kelman, dan Frank, HSCL telah menjadi salah satu alat ukur yang umum digunakan dalam penelitian klinis (Schmalbach et al, 2019). HSCL-10 merupakan alat ukur unidimensional turunan dari berbagai versi HSCL sebelumnya seperti HSCL-60 dan HSCL25 (Kleppang \& Hagquist, 2016). HSCL-10 terdiri dari 10 butir yang digunakan untuk 
mengukur tingkat distres psikologis pada orang dewasa dan memiliki reliabilitas serta validitas yang baik (Syed et al, 2008). Sama seperti pada HSCL-25, HSCL-10 juga mengukur distres psikologis berdasarkan gejala kecemasan dan depresi yang muncul pada empat butir gejala kecemasan dan enam butir gejala depresi. Butir pada HSCL-10 dapat direspon menggunakan skala Likert 1 yang berarti "tidak sama sekali" sampai 4 yang berarti "sangat mengganggu". Skor distres didapatkan dengan merata-ratakan total seluruh butir, dan rata-rata skor e" 1.85 mengindikasikan adanya distres psikologis pada individu (Strand et al., 2003). Reliabilitas internal HSCL-10 dalam penelitian ini diukur menggunakan Alpha Cronbach dan didapatkan hasil sebesar .90 .

\section{The 14-Item Resilience Scale (RS-14)}

RS-14 dirancang oleh Wagnild \& Young (1993) untuk mengukur resiliensi. Alat ukur ini terdiri dari 14 butir dan dapat digunakan di berbagai kelompok usia mulai dari remaja hingga lanjut usia (Ahern et al., 2006). Adapun skala yang digunakan yaitu mulai 1 "sangat tidak setuju" sampai 7 "sangat setuju". Semakin tinggi skor mengindikasikan resiliensi yang semakin baik. Skor di atas 90 mengindikasikan tingkat resiliensi yang tinggi, skor 82-90 cukup tinggi, 65-81 menandakan resiliensi sedang, 64-57 rendah, dan skor di bawah 56 mengindikasikan resiliensi yang sangat rendah (Wagnild, 2016). Uji Alpha Cronbach dilakukan untuk mendapatkan reliabilitas internal dari RS-14, dan didapatkan nilai sebesar .90.

\section{Mental Health Continuum - Short Form (MHC-SF)}

Alat ukur ini pertama kali disusun oleh Keyes (2002). Awalnya, MHC terdiri dari 40 butir, kini MHC versi pendek telah disusun. MHC-SF terdiri dari 14 butir yang digunakan untuk mengukur tingkat well-being secara emosional, psikologis, dan sosial (Lamers et al, 2012). MHC-SF direspon menggunakan skala Likert 1-6, di mana skor 0 merepresentasikan "tidak pernah" hingga skor 5 merepresentasikan “setiap hari” (Keyes, 2002). Skor MHC-SF dapat dihitung skor totalnya secara Likert dan juga bisa dikategorikan berdasarkan ketentuan (Keyes, 2009). Individu dapat dikatakan memiliki well-being yang flourishing (sangat baik) ketika individu menjawab "setiap hari" atau "hampir setiap hari" pada setidaknya salah satu item hedonic well-being (butir nomor 1-3) dan dan setidaknya enam dari sebelas butir keberfungsian (butir nomor 4-14). Sebaliknya, individu dianggap memiliki well-being yang languishing (sangat buruk) jika ia menjawab "tidak pernah" atau "sesekali" pada setidaknya salah satu item hedonic well-being (butir nomor 1-3) dan dan setidaknya enam dari sebelas butir keberfungsian (butir nomor 4-14). Koefisien reliabilitas Alpha Cronbach dari MHC-SF dalam penelitian ini sebesar 95 . 


\section{Analisis statistik}

Penelitian ini menggunakan analisis statistik mediasi menggunakan Hayes' PROCESS macro pada Statistical Package for the Social Sciences (SPSS) versi 24 (Hayes, 2018). Pada penelitian ini, ditetapkan hipotesis bahwa resiliensi mempengaruhi distres psikologis (jalur $a$ ), yang selanjutnya berpengaruh terhadap wellbeing (jalur $b$ ). Indirect effect didapatkan dengan mengalikan $a$ dengan $b$ (Hayes, 2018). Direct effect ( $c^{\prime}$ ) adalah pengaruh resiliensi terhadap well-being setelah mengontrol distres psikologis. Keseluruhan indirect effect dan direct effect disebut dengan istilah total effect. Distres psikologis dianggap sebagai mediator penuh apabila direct effect tidak signifikan, dan mediator sebagian (partial mediator) apabila directeffect signifikan (Hayes, 2018).

\section{Hasil}

\section{Analisis awal}

Demografi partisipan dapat dilihat pada Tabel 1. Partisipan penelitian ini terdiri dari 260 dewasa di Indonesia dengan rata-rata usia 25.3 (SD = 7.8). Sebagian besar partisipan merupakan perempuan (80.4\%), masuk ke dalam kategori usia dewasa muda (89.6\%), beragama Islam (69.2\%), dengan pendidikan terakhir SMA (51.9\%).

\section{Tabel 1}

\section{Demografi Partisipan}

\begin{tabular}{lll}
\hline Data Demografi & $n$ & $\%$ \\
\hline Jenis Kelamin & & \\
$\quad$ Perempuan & 209 & $80.4 \%$ \\
Laki-laki & 51 & $19.6 \%$ \\
Usia & & \\
Dewasa Muda (19-35 tahun) & 233 & $89.6 \%$ \\
Dewasa Madya (36-55 tahun) & 27 & $10.4 \%$ \\
Agama & & \\
Islam & 180 & $69.2 \%$ \\
Kristen & 55 & $21.2 \%$ \\
Katolik & 12 & $4.6 \%$ \\
Hindu & 2 & $.8 \%$ \\
Buddha & 9 & $3.5 \%$ \\
Lainnya & 2 & $.8 \%$ \\
Pendidikan & & \\
SMA & 135 & $51.9 \%$ \\
Diploma & 13 & $5 \%$ \\
Sarjana & 103 & $39.6 \%$ \\
Pascasarjana & 9 & $3.5 \%$ \\
\hline
\end{tabular}

Catatan. $N=260$. 
Peneliti kemudian melakukan analisis deskriptif setiap alat ukur dan didapatkan hasil seperti pada Tabel 2. Bila dilihat berdasarkan kategori di Tabel 3, sebanyak 22.9\% partisipan memiliki resiliensi rendah atau sangat rendah, setengah dari partisipan (50\%) memiliki tingkat resiliensi yang sedang, dan 21.1\% memiliki resiliensi cukup tinggi dan tinggi.
Untuk kategori distres psikologis, sebagian besar partisipan masuk ke dalam kategori memiliki distres psikologis (59.7\%). Adapun sebanyak $11.5 \%$ partisipan masuk ke dalam kategori well-being yang flourishing, 14.6\% masuk ke dalam kategori languishing, dan sisanya memiliki tingkat well-being yang sedang.

\section{Tabel 2}

Statistik Deskriptif

\begin{tabular}{llllll}
\hline & $M$ & $S D$ & $\begin{array}{l}\text { Possible } \\
\text { Range }\end{array}$ & $\begin{array}{l}\text { Actual } \\
\text { Range }\end{array}$ & Cronbach $\alpha$ \\
\hline Usia & 25.3 & 7.8 & - & - & - \\
Resiliensi & 71.5 & 12.9 & $14-98$ & $31-98$ & .90 \\
Distres psikologis & 2.23 & .82 & $1-4$ & $1-4$ & .90 \\
Well-being & 41.2 & 15.5 & $0-70$ & $5-70$ & .95 \\
\hline
\end{tabular}

Tabel 3

Kategorisasi Variabel

\begin{tabular}{lll}
\hline Variabel & $n$ & $\%$ \\
\hline Resiliensi & & \\
$\quad$ Sangat Rendah & 34 & $13 . .1 \%$ \\
Rendah & 41 & $15.8 \%$ \\
Sedang & 130 & $50 \%$ \\
Cukup Tinggi & 37 & $14.2 \%$ \\
Tinggi & 18 & $6.9 \%$ \\
Distres psikologis & & \\
$\quad$ Tidak Ada Indikasi Distres & 105 & $40.3 \%$ \\
$\quad$ Ada Indikasi Distres & 155 & $59.7 \%$ \\
Well-being & & \\
$\quad$ Flourishing & 30 & $11.5 \%$ \\
$\quad$ Sedang & 192 & $73.9 \%$ \\
Languishing & 38 & $14.6 \%$ \\
\hline Catatan. & & \\
\hline
\end{tabular}

Catatan. $N=260$ 


\section{Analisis mediasi}

Analisis mediasi dilakukan untuk menguji apakah distres psikologis memediasi hubungan antara resiliensi dan well-being pada dewasa di Indonesia. Ditemukan bahwa resiliensi signifikan memprediksi distres psikologis $(\hat{a}=-.47, S E=.04, p<.000)$, dan distres psikologis signifikan memprediksi well-being $(\hat{a}=-.30, S E=.09, p<.000)$. Hasil ini mendukung hipotesis mediasi, dengan indirect effect diuji menggunakan perkiraan bootstrap 5000 sampel. Hasil menunjukkan bahwa distres psikologis berperan sebagai mediator parsial dalam hubungan antara resiliensi dan well-being $(\hat{a}=.14 ; S E=.03 ; 95 \%$ CI $[.09, .19])$. Hubungan antara resiliensi dan well-being sebagian bisa dijelaskan melalui jalur tidak langsung, di mana resiliensi mempengaruhi distres psikologis, yang kemudian mempengaruhi well-being.

\section{Tabel 4}

Analisis Mediasi

\begin{tabular}{lllllll}
\hline & $t$ & $p$ & $\beta$ & $F$ ratio & $d f$ & $R^{2}$ \\
\hline $\begin{array}{l}\text { Model Variabel Mediator } \\
\quad \text { Overall Model }\end{array}$ & & .000 & & 71.64 & 1,258 & .22 \\
$\quad \begin{array}{l}\text { Resiliensi } \\
\text { Model Variabel Terikat }\end{array}$ & -8.46 & $.000^{*}$ & -.47 & & & \\
$\quad \begin{array}{l}\text { Overall Model } \\
\text { Resiliensi }\end{array}$ & 10.87 & .000 & & 138.93 & 2,257 & .52 \\
$\quad$ Distres Psikologis & -6.11 & $.000^{*}$ & .53 & & & \\
\hline & $\beta$ & Boot SE & Boot 95\% CI & & \\
\hline Indirect Effect & .14 & .03 & {$[.09, .19]$} & & & \\
\hline
\end{tabular}

Catatan. $N=260$. Bootstrap sample size $=5000 ; \mathrm{LL}=$ low limit; $\mathrm{CI}=$ confidence interval; $\mathrm{UL}=$ upper limit; ${ }^{*} p<.001$.

\section{Gambar 1}

Efek Mediasi Parsial Distres Psikologis antara Resiliensi dan Well-being

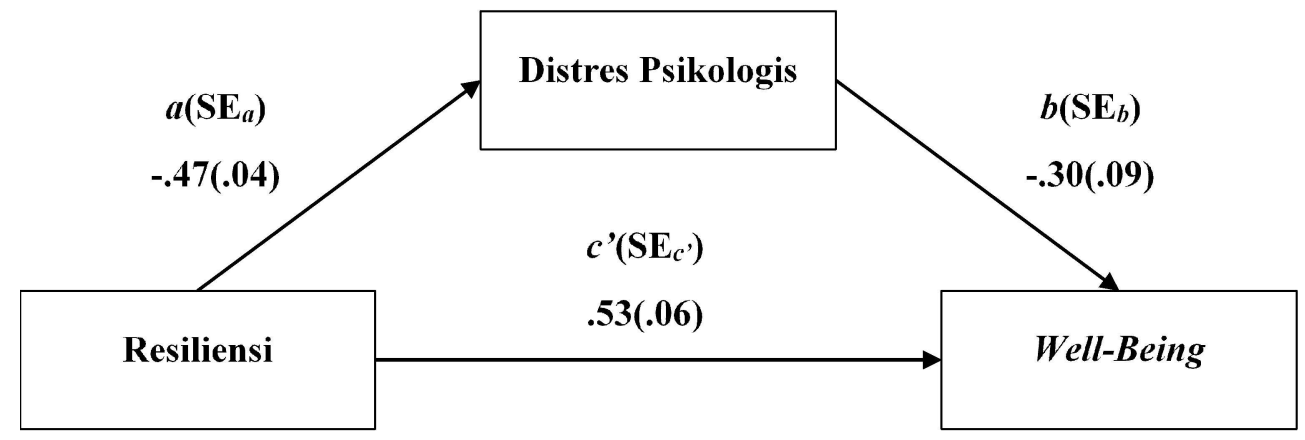

\section{Pembahasan}

Penelitian ini bertujuan untuk menganalisis hubungan resiliensi dan well- being melalui mekanisme distres psikologis pada dewasa di Indonesia. Dari hasil pengukuran yang dilakukan, terlihat bahwa 
sebagian besar partisipan penelitian menunjukkan adanya indikasi distres psikologis pada saat pengambilan data. Hasil ini salah satunya bisa berkaitan dengan situasi pandemi COVID-19 yang sedang berlangsung ketika penelitian dilaksanakan. Dari penelitian sebelumnya, kebijakan untuk tinggal di rumah dan menjaga jarak berhubungan dengan peningkatan kemunculan stres, gejala depresi, maupun kecemasan (Marroquín et al., 2020). Meski masyarakat sudah mulai bergerak menuju New Normal, keterbatasan dalam berhubungan dengan orang terdekat, kekhawatiran mengenai penyebaran virus, serta ketidakpastian kondisi finansial masih dirasakan dan berpengaruh pada kondisi psikologis masyarakat. Bila melihat persebaran resiliensi, partisipan lebih banyak berada pada kategori sedang dan cenderung ke rendah. Hal ini mengindikasikan bahwa tingkat resiliensi masyarakat Indonesia masih dapat dikembangkan untuk memastikan kemampuan adaptasi yang lebih baik di berbagai situasi.

Dari hasil penelitian ini, ditemukan bahwa distres psikologis berperan sebagai mediator parsial dalam hubungan antara resiliensi dan well-being. Sejalan dengan penelitian sebelumnya, penelitian ini menemukan bahwa resiliensi memprediksi adanya distres psikologis yang lebih rendah pada individu (Pinquart, 2009). Distres psikologis melibatkan penilaian kognitif akan situasi dan perasaan memiliki kendali (sense of control) menjadi hal utama yang bisa mempengaruhi tingkat distres psikologi (Mirowsky \& Ross, 2017). Individu dengan resiliensi juga memiliki self-efficacy yang lebih tinggi, serta mampu membuat mereka memandang diri sendiri memiliki kemampuan menghadapi situasi stres (Lightsey, 2006). Hal ini juga berkaitan dengan karakteristik resiliensi yaitu optimis, di mana individu yang resilien dapat memandang situasi yang sulit lebih positif, serta bukan sebagai potensi ancaman (Souri \& Hasanirad, 2011).

Temuan penelitian ini mendukung model cognitive appraisal theory of stress dari (Lazarus \& Folkman, 1984) yang menekankan pentingnya peran penilaian (appraisal) terhadap situasi stres dalam distres psikologis dan well-being. Penilaian yang berbeda terhadap situasi stres bisa memunculkan reaksi yang berbeda pula, sehingga penilaian yang lebih positif akan memunculkan reaksi yang lebih adaptif. Penanganan stres yang lebih baik kemudian berkontribusi terhadap persepsi well-being yang lebih tinggi. Peran resiliensi terhadap well-being, dengan kata lain, dapat dijelaskan melalui mekanisme persepsi positif baik dalam menilai diri maupun juga lingkungan sekitar (Mak et al, 2011).

Meski ditemukan adanya efek mediasi dari distres psikologis, hasil penelitian ini melihat adanya efek langsung dari resiliensi terhadap well-being yang lebih kuat. Hasil ini salah satunya berkaitan dengan sifat multi domain dari konstruk resiliensi. Model mediasi distres psikologis melihat pengaruh resiliensi 
terhadap well-being melalui domain optimisme dan self-efficacy dari resiliensi (Lightsey, 2006; Souri \& Hasanirad, 2011). Adapun resiliensi memiliki domain lain yang juga berperan terhadap well-being seperti adanya tujuan dan makna hidup (Ledesma, 2014; Russo-Netzer, 2019) dan dukungan sosial (Rossouw \& Rossouw, 2016). Individu yang resilien cenderung memiliki visi dan tujuan hidup yang ingin dicapai serta persepsi ketersediaan dukungan sosial yang memadai, membuat mereka menilai hidup mereka lebih puas dan sejahtera. Domain-domain ini tidak tercermin dalam model mediasi yang diujikan penelitian ini, sehingga mungkin muncul dalam bentuk efek langsung antara resiliensi dan well-being.

Penelitian ini memiliki beberapa limitasi dalam pelaksanaannya. Pertama, pengambilan data dalam penelitian ini dilakukan secara crosssectional, di mana semua variabel diukur pada satu waktu yang sama. Oleh karenanya, urutan kemunculan variabel (variabel apa yang mempengaruhi kemunculan variabel lainnya) tidak dapat sepenuhnya diinterpretasikan. Arah kausalitas dari hasil penelitian perlu di interpretasikan secara hati-hati. Kedua, terdapat kemungkinan terjadinya bias akibat pengambilan data menggunakan self-report yang dilakukan secara online. Penelitian berikutnya dapat mempertimbangkan metode pengambilan data secara tatap muka dan mengumpulkan data tambahan di luar selfreport. Terkait waktu pelaksanaan, penelitian ini dilaksanakan pada situasi pandemi COVID-
19. Namun, penelitian ini belum memperhitungkan dampak pandemi COVID-19 dalam pengukuran variabel, sehingga belum bisa ditarik kesimpulan mengenai efek pandemi terhadap dinamika variabel yang ada. Penelitian ini juga menemukan efek langsung yang kuat dalam hubungan antara resiliensi dan wellbeing. Hal ini menandakan adanya aspek resiliensi lain yang erat hubungannya dengan well-being dan belum diperhitungkan dalam model mediasi penelitian ini. Penelitian lanjutan dapat melihat aspek-aspek resiliensi lain selain aspek kognitif dan melihat dinamikanya dalam mempengaruhi well-being .

Meski terdapat beberapa limitasi dalam penelitian ini, penelitian ini memberikan pemahaman lebih lanjut mengenai dinamika antara resiliensi, distres psikologis, serta wellbeing melalui peran penilaian kognitif pada dewasa di Indonesia. Penilaian kognitif melalui persepsi distres terlihat memediasi secara sebagian hubungan antara resiliensi dan wellbeing. Ketika seseorang memiliki resiliensi yang baik, maka penilaian kognitif terhadap situasinya semakin positif. Melihat sumber stres tidak lagi sebagai ancaman, sehingga menurunkan distres yang dimiliki. Distres psikologis yang rendah kemudian berpengaruh terhadap well-being yang semakin tinggi pula.

Hasil dari penelitian ini memiliki beberapa implikasi dalam pengembangan intervensi psikologis terkait resiliensi dan distres psikologis berikutnya. Melihat peran distres psikologis dalam menjembatani 
hubungan antara resiliensi dan well-being, pengembangan intervensi dengan target aspek kognitif yang berperan dalam distres psikologis dapat menjadi salah satu alternatif. Peningkatan fleksibilitas kognitif dapat menjadi salah satu strategi intervensi, melihat rendahnya fleksibilitas kognitif diasosiasikan dengan perilaku menghindar yang bisa memperburuk distres psikologis (Palm \& Follette, 2011). Intervensi ini juga dapat ditambah dengan intervensi mindfulness yang menyasar reaktivitas emosi dan mengurangi penilaian negatif dari stres (Scott-Sheldon et al., 2020).

\section{Simpulan}

Distres psikologis berperan sebagai mediator dalam hubungan antara resiliensi dan well-being pada dewasa di Indonesia. Semakin tinggi resiliensi, maka distres psikologis individu semakin rendah, yang kemudian berpengaruh terhadap peningkatan well-being. Hasil penelitian ini menekankan bagaimana pemaknaan terhadap pengalaman berperan penting dalam penilaian well-being yang dirasakan oleh individu. Untuk mengatasi dampak negatif dari situasi stres terhadap kondisi psikologis, intervensi yang menyasar peningkatan resiliensi serta fleksibilitas kognitif dapat menjadi salah satu alternatif penanganan.

\section{Saran}

Berdasarkan penelitian yang sudah dilakukan, terdapat beberapa saran bagi peneliti selanjutnya yaitu mengeksplor lebih jauh aspek resiliensi yang lain seain kognitif dan menambahkan bentuk intervensi yang berbeda sehingga data lebih kaya, melakukan pengambilan data dengan metode langsung sehingga data tidak bias, dan mengembangkan topik penelitian dengan menggunakan aspek lain dari resiliensi. Kemudian peneliti selanjutnya juga diharapkan untuk menginkorporasi situasi lingkungan yang aktual dalam penelitiannya.

\section{Referensi}

Ahern, N. R., Kiehl, E. M., Lou Sole, M., \& Byers, J. (2006). A Review of instruments measuring resilience. Issues in Comprehensive Pediatric Nursing, 29(2), 103-125. https://doi.org/10.1080/ 01460860600677643

Bacchi, S., \& Licinio, J. (2017). Resilience and psychological distress in psychology and medical students. Academic Psychiatry, 41(2), 185-188. https://doi.org/ 10.1007/s40596-016-0488-0

Carver, C. S., Scheier, M. F., \& Segerstrom, S. C. (2010). Optimism. Clinical Psychology Review, 30(7), 879-889. https://doi.org/ 10.1016/j.cpr.2010.01.006

Cher, J. M., \& Aileen, M. P. (2015). Resilience attributes among university students: A comparative study of psychological distress, sleep disturbances and mindfulness. European Scientific Journal, 11(5), 33-48.

Datta Gupta, N., Etcoff, N. L., \& Jaeger, M. M. (2016). Beauty in mind: The effects of physical attractiveness on psychological well-being and distress. Journal of Happiness Studies, 17(3), 1313-1325. https://doi.org/10.1007/s10902-0159644-6

Fedina, L., Nam, B., Jun, H.-J., Shah, R., Von Mach, T., Bright, C. L., \& DeVylder, J. (2021). Moderating effects of resilience on depression, psychological distress, and 
suicidal ideation associated with interpersonal violence. Journal of Interpersonal Violence, 36(3-4), NP1335-1358NP. https://doi.org/ $10.1177 / 0886260517746183$

Gallè, F., Sabella, E. A., Da Molin, G., De Giglio, O., Caggiano, G., Di Onofrio, V., Ferracuti, S., Montagna, M. T., Liguori, G., Orsi, G. B., \& Napoli, C. (2020). Understanding knowledge and behaviors related to CoViD-19 epidemic in Italian undergraduate students: The EPICO study. International Journal of Environmental Research and Public Health, 17(10), 3481. https://doi.org/ 10.3390/ijerph17103481

Harker, R., Pidgeon, A. M., Klaassen, F., \& King, S. (2016). Exploring resilience and mindfulness as preventative factors for psychological distress burnout and secondary traumatic stress among human service professionals. Work, 54(3), 631-637. https://doi.org/ 10.3233/WOR-162311

Harms, B. P. D., Brady, L., \& Wood, D. (2018). Resilience and well-being. In E. Diener, S. Oishi, \& L. Tay (Eds.), Handbook of wellbeing (pp. 1-12). DEF Publishers.

Hayes, A. F. (2018). Introduction to mediation, moderation, and conditional process analysis, second edition: A regressionbased approach. In the Guilford Press.

Iacoviello, B. M., \& Charney, D. S. (2014). Psychosocial facets of resilience: Implications for preventing posttrauma psychopathology, treating trauma survivors, and enhancing community resilience. European Journal of Psychotraumatology, 5(1), 23970. https:/ /doi.org/10.3402/ejpt.v5.23970

Keyes, C. L. M. (2002). The mental health continuum: From languishing to flourishing in life. Journal of Health and Social Behavior. https://doi.org/ 10.2307/3090197

Keyes, C. L. M. (2009). Brief description of the mental health continuum short form
(MHC-SF). American Journal of Public Health.

Kleppang, A. L., \& Hagquist, C. (2016). The psychometric properties of the Hopkins Symptom Checklist-10: A rasch analysis based on adolescent data from Norway. Family Practice, 33(6), 740-745. https:/ /doi.org/10.1093/fampra/cmw091

Lamers, S. M. A., Glas, C. A. W., Westerhof, G. J., \& Bohlmeijer, E. T. (2012). Longitudinal evaluation of the Mental Health Continuum-Short Form (MHC-SF). European Journal of Psychological Assessment, 28(4), 290-296. https:// doi.org/10.1027/1015-5759/a000109

Lazarus, R. S., \& Folkman, S. (1984). Stress, appraisal, and coping. Springer Pub. Co.,.

Lebares, C. C., Guvva, E. V, Ascher, N. L., O'Sullivan, P. S., Harris, H. W., \& Epel, E. S. (2018). Burnout and stress among US surgery residents: Psychological distress and resilience. Journal of the American College of Surgeons, 226(1), 80-90. h ttps://doi.org/10.1016/ j.jamcolsurg.2017.10.010

Ledesma, J. (2014). Conceptual frameworks and research models on resilience in leadership. SAGE Open, 4(3), 215824401454546-215824401454546. h t tp s: / / do i.org / 10.1177 / 2158244014545464

Li, Z.-S., \& Hasson, F. (2020). Resilience, stress, and psychological well-being in nursing students: A systematic review. Nurse Education Today, 90, 104440. https:// doi.org/10.1016/j.nedt.2020.104440

Lightsey, O. R. (2006). Resilience, meaning, and well-being. The Counseling Psychologist, 34(1), 96-107. https://doi.org/10.1177/ 0011000005282369

Liu, Y., Wang, Z., Zhou, C., \& Li, T. (2014). Affect and self-esteem as mediators between trait resilience and psychological adjustment. Personality and Individual Differences, 66, 92-97. https://doi.org/ 10.1016/j.paid.2014.03.023 
Luhmann, M. (2014). Long-term changes in well-being. In Encyclopedia of Quality of Life and Well-Being Research (pp. 37033706). Springer Netherlands. https:// doi.org/10.1007/978-94-007-07535_1704

Mak, W. W. S., Ng, I. S. W., \& Wong, C. C. Y. (2011). Resilience: Enhancing well-being through the positive cognitive triad. Journal of Counseling Psychology, 58(4), 610-617. https://doi.org/10.1037/ a0025195

Makwana, N. (2019). Disaster and its impact on mental health: A narrative review. Journal of Family Medicine and Primary Care, 8(10), 3090. https://doi.org/ 10.4103/jfmpc.jfmpc_893_19

Marino, C., Gini, G., Vieno, A., \& Spada, M. M. (2018). The associations between problematic Facebook use, psychological distress and well-being among adolescents and young adults: A systematic review and meta-analysis. Journal of Affective Disorders, 226, 274281. https://doi.org/10.1016/ j.jad.2017.10.007

Marroquín, B., Vine, V., \& Morgan, R. (2020). Mental health during the COVID-19 pandemic: Effects of stay-at-home policies, social distancing behavior, and social resources. Psychiatry Research, 293, 113419. https://doi.org/10.1016/ j.psychres.2020.113419

Masten, A. S. (2018). Resilience theory and research on children and families: Past, present, and promise. Journal of Family Theory \& Review, 10(1), 12-31. https:// doi.org/10.1111/jftr.12255

McCrea, R., Walton, A., \& Leonard, R. (2014). A conceptual framework for investigating community wellbeing and resilience. Rural Society, 23(3), 270-282. https:// d o i . o r g / 10 . 1080 / 10371656.2014.11082070

Mirowsky, J., \& Ross, C. E. (2017). Social causes of psychological distress. In Social
Causes of Psychological Distress. https:/ /doi.org/10.4324/9781315129464

Organization, W. H. (2020). Mental health and COVID-19. https://www.euro.who.int/ en/health-topics/health-emergencies/ coronavirus-covid-19/publicationsa n d - te c h n i c a l-g u i dance / noncommunicable-diseases/mentalhealth-and-covid-19

Palm, K. M., \& Follette, V. M. (2011). The roles of cognitive flexibility and experiential avoidance in explaining psychological distress in survivors of interpersonal victimization. Journal of Psychopathology and Behavioral Assessment, 33(1), 79-86. https:// doi.org/10.1007/s10862-010-9201-x

Pietrzak, R. H., Johnson, D. C., Goldstein, M. B., Malley, J. C., Rivers, A. J., Morgan, C. A., \& Southwick, S. M. (2010). Psychosocial buffers of traumatic stress, depressive symptoms, and psychosocial difficulties in veterans of operations enduring freedom and iraqi freedom: The role of resilience, unit support, and postdeployment social support. Journal of Affective Disorders, 120(1-3), 188192. https://doi.org/10.1016/ j.jad.2009.04.015

Pinquart, M. (2009). Moderating effects of dispositional resilience on associations between hassles and psychological distress. Journal of Applied Developmental Psychology, 30(1), 53-60. h t tp s: / / do i.org / 10.1016 / j.appdev.2008.10.005

Rossouw, P. J., \& Rossouw, J. G. (2016). The predictive 6 -factor resilience scale: Neurobiological fundamentals and the predictive 6-factor resilience scale: Neurobiological fundamentals and organizational application. International Journal of Neuropsychotherapy, 4(1), 31-45. https://doi.org/10.12744/ ijnpt.2016.0031-0045

Russo-Netzer, P. (2019). Prioritizing meaning as a pathway to meaning in life and well- 
being. Journal of Happiness Studies, 20(6), 1863-1891. https://doi.org/ $10.1007 / \mathrm{s} 10902-018-0031-\mathrm{y}$

Schmalbach, B., Zenger, M., Tibubos, A. N., Kliem, S., Petrowski, K., \& Brähler, E. (2019). Psychometric properties of two brief versions of the Hopkins Symptom Checklist: HSCL-5 and HSCL-10. Assessment, $107319111986091-$ 107319111986091. https://doi.org/ $10.1177 / 1073191119860910$

Scott-Sheldon, L. A. J., Gathright, E. C., Donahue, M. L., Balletto, B., Feulner, M. M., DeCosta, J., Cruess, D. G., Wing, R. R., Carey, M. P., \& Salmoirago-Blotcher, E. (2020). Mindfulness-based interventions for adults with cardiovascular disease: A systematic review and meta-analysis. Annals of Behavioral Medicine, 54(1), 67-73. https://doi.org/10.1093/abm/ kaz020

Souri, H., \& Hasanirad, T. (2011). Relationship between resilience, optimism and psychological well-being in students of medicine. Procedia - Social and Behavioral Sciences, 30, 1541-1544. h t tps: / / doi.org / 10.1016 / j.sbspro.2011.10.299

Southwick, S. M., Vythilingam, M., \& Charney, D. S. (2005). The psychobiology of depression and resilience to stress: Implications for prevention and treatment. Annual Review of Clinical Psychology, 1(1), 255-291. https:// d o i . o r g / $100.1146 /$ annurev.clinpsy.1.102803.143948

Stomff, M. (2019). Development of resilience in children and teenagers: A meta-analysis of empirical studies from 2006-2017 (Personality and mental state). Romanian Journal of Psychological Studies. abstract $=3562204$ https://ssrn.com/

Strand, B. H., Dalgard, O. S., Tambs, K., \& Rognerud, M. (2003). Measuring the mental health status of the Norwegian population: A comparison of the instruments SCL-25, SCL-10, SCL-5 and MHI-5 (SF-36). Nordic Journal of Psychiatry, 57(2), 113-118. https:// doi.org/10.1080/08039480310000932

Syed, H. R., Zachrisson, H. D., Dalgard, O. S., Dalen, I., \& Ahlberg, N. (2008). Concordance between Hopkins Symptom Checklist (HSCL-10) and Pakistan Anxiety and Depression Questionnaire (PADQ), in a rural self-motivated population in Pakistan. BMC Psychiatry, 8(1), 59. https://doi.org/10.1186/1471-244X-859

Tian, X., Gao, Q., Li, G., Zou, G., Liu, C., Kong, L., \& $\mathrm{Li}, \mathrm{P}$. (2016). Resilience is associated with low psychological distress in renal transplant recipients. General Hospital Psychiatry, 39, 86-90. https://doi.org/ 10.1016/j.genhosppsych.2015.12.004

Wagnild, G. M. (2016). No title the resilience scale: User's guide guide for the US english version of the resilience scale and the 14-item resilience scale ver. 3.33. Resilience Center, Montana, USA.

Wagnild, G. M., \& Young, H. M. (1993). Development and psychometric evaluation of the resilience scale. Journal of Nursing Measurement.

Wald, H. S. (2020). Optimizing resilience and wellbeing for healthcare professions trainees and healthcare professionals during public health crises - Practical tips for an 'integrative resilience' approach. Medical Teacher, 42(7), 744755. https://doi.org/10.1080/ 0142159X.2020.1768230

Wang, J. H., Tan, S., \& Raubenheimer, K. (2020). Rethinking the role of senior medical students in the COVID 19 response. Medical Journal of Australia, 212(10), 490. https://doi.org/10.5694/ mja2.50601

Weeranakin, P., \& Promphakping, B. (2018). Local meanings of wellbeing and the construction of wellbeing indicators. Social Indicators Research, 138(2), 689- 
703. https://doi.org/10.1007/s11205017-1692-3

Wersebe, H., Lieb, R., Meyer, A. H., Hofer, P., \& Gloster, A. T. (2018). The link between stress, well-being, and psychological flexibility during an acceptance and commitment therapy self-help intervention. International Journal of Clinical and Health Psychology, 18(1), 60-68. https://doi.org/10.1016/ j.ijchp.2017.09.002

Zacher, H., \& Rudolph, C. W. (2021). Individual differences and changes in subjective wellbeing during the early stages of the
COVID-19 pandemic. American Psychologist, 76(1), 50-62. https:// doi.org/10.1037/amp0000702

Zhang, H., Zhao, Q., Cao, P., \& Ren, G. (2017). Resilience and quality of life: Exploring the mediator role of social support in patients with breast cancer. Medical Science Monitor, 23, 5969-5979. https:/ /doi.org/10.12659/MSM.907730

Received 28 November 2020 Revised 5 May 2021 Accepted 31 July 2021 
